\title{
Aleksander Birkenmajer jako wizytator Zbiornicy Księgozbiorów Zabezpieczonych we Wrocławiu ${ }^{1}$
}

\begin{abstract}
STReszczenie. Jeden z najwybitniejszych polskich bibliologów XX wieku prof. Aleksander Birkenmajer przeprowadził w 1949 roku na zlecenie Ministerstwa Oświaty pierwszą w swojej karierze bibliotekarskiej wizytację Biblioteki Uniwersyteckiej oraz Zbiornicy Księgozbiorów Zabezpieczonych we Wrocławiu. W instytucjach znajdowały się poddane ochronie materiały biblioteczne. Do Zbiornicy Księgozbiorów Zabezpieczonych w latach 1947-1949 zwieziono z terenu Dolnego Śląska około 900000 tomów, głównie poniemieckiej proweniencji. Bibliolog w sporządzonym sprawozdaniu wskazał na występujące problemy oraz sposoby ich przezwyciężenia. Wysoko ocenił pracowników, którym przyszło działać w trudnym powojennym okresie. Birkenmajer okazał się wnikliwym, rzetelnym oraz obiektywnym wizytatorem. Sprawozdanie jest cennym dokumentem źródłowym pozwalającym poznać fragment historii wrocławskiej zbiornicy oraz Biblioteki Uniwersyteckiej. Powinno być wykorzystane w przyszłych pracach badawczych związanych z odbudową bibliotek i bibliotekarstwa na Dolnym Śląsku oraz w Polsce.
\end{abstract}

SŁowA KLuczowe: Aleksander Birkenmajer, ochrona zbiorów bibliotecznych, Wrocław, Dolny Śląsk, zbiornica książek, XX wiek.

Jeden z najwybitniejszych polskich bibliologów XX wieku prof. Aleksander Birkenmajer doczekał się licznych artykułów na swój temat². Dotychczas

${ }^{1}$ Projekt został sfinansowany ze środków Narodowego Centrum Nauki przyznanych na podstawie decyzji numer DEC-2011/03/B/HS2/05446.

2 Znane i wysoko cenione są osiągnięcia naukowe Aleksandra Birkenmajera w dziedzinie historii, nauk ścisłych, filozofii średniowiecza czy dziejów książki. Warto podkreślić, że opublikowany w 2007 roku tom „Roczników Bibliotecznych” (51) został „dedykowany pamięci Aleksandra Birkenmajera wybitnego historyka nauki, bibliologa, bibliotekarza, w czterdziestą rocznicę śmierci". O bogatej działalności Birkenmajera napisali między innymi: Z. Ameisenowa, Aleksander Birkenmajer jako bibliotekarz i uczony, „Roczniki Biblioteczne” 1961, t. 5, s. 1-9; J. Baumgart, Aleksander Birkenmajer jako 
jednak w literaturze przedmiotu nie został podjęty temat związany z działalnością naukowca w charakterze wizytatora. Ponad pół wieku temu na zlecenie Naczelnej Dyrekcji Bibliotek Ministerstwa Oświaty przeprowadził pierwszą w swojej karierze bibliotekarskiej kilkudniową wizytację Biblioteki Uniwersyteckiej oraz Zbiornicy Księgozbiorów Zabezpieczonych we Wrocławiu ${ }^{3}$. Sporządzone sprawozdanie, przechowywane w Archiwum Akt Nowych w Warszawie ${ }^{4}$, stało się podstawą do napisania niniejszego artykułu.

Uniwersytet i politechnika w 1949 roku stanowiły jedyną wyższą uczelnię we Wrocławiu. Posiadały, oprócz bibliotek zakładowych i instytutowych, trzy księgozbiory ogólne:

- Bibliotekę Uniwersytecką - placówka ta służyła całej uczelni, ale w praktyce zaspokajała potrzeby Wydziału Humanistycznego, Wydziału Prawa i Administracji, Wydziału Nauk Przyrodniczych oraz Wydziału Rolniczego,

- Bibliotekę Politechniczna, która funkcjonowała na potrzeby Politechniki Wrocławskiej i wspólnego z uniwersytetem Wydziału Matematyczno-Fizyczno-Chemicznego,

dyrektor Biblioteki Uniwersyteckiej w Poznaniu i Biblioteki Jagiellońskiej w Krakowie, „,Roczniki Biblioteczne" 1969, t. 13, s. 178-181; idem, Działalność bibliotekarska Aleksandra Birkenmajera, „Roczniki Biblioteczne” 1961, t. 5, s. 11-21; B. Bieńkowska, Aleksandra Birkenmajera koncepcja historii ksiażki, „Przegląd Biblioteczny” 1978, t. 46, s. 155-162; eadem, Czterdzieści lat Katedry prof. Aleksandra Birkenmajera, „Kwartalnik Historii Nauki i Techniki” 1991, nr 3, s. 65-94; Z. Ciechanowska, Aleksander Birkenmajer o historii bibliotek, „Roczniki Biblioteczne" 1969, t. 13, s. 223-238; J. Dobrzycki, Aleksander Birkenmajer jako historyk nauki, „Przegląd Biblioteczny” 1978, nr 46, s. 169-173; A. Lewicka-Kamińska, Dorobek naukowy Aleksandra Birkenmajera w badaniach nad starymi drukami i oprawa ksiażki zabytkowej, ",Roczniki Biblioteczne" 1968, t. 12, s. 1-15; H. Lipska, Wspomnienie o pracy Aleksandra Birkenmajera w Bibliotece Jagiellońskiej (1919-1939), "Roczniki Biblioteczne” 1968, t. 12, s. 17-29; H. Więckowska, Księgoznawstwo w kręgu wielkiej nauki-Aleksander Birkenmajer, w: Twórcy nowoczesnego bibliotekarstwa polskiego, red. B. Kocowski, Wrocław 1974, s. 41-52; J. Wojakowski, Wkład Aleksandra Birkenmajera do nowoczesnego bibliotekarstwa, „Przegląd Biblioteczny" 1978, t. 46, s. 163-168; J. Zathey, Działalność Aleksandra Birkenmajera w zakresie rękopisoznawstwa, „Roczniki Biblioteczne” 1969, t. 13, s. 197-221.

3 Archiwum Akt Nowych w Warszawie (dalej: AAN), Ministerstwo Oświaty. Naczelna Dyrekcja Bibliotek. Wydział Bibliotek Naukowych, sygn. 6943, k. 39 - Aleksander Birkenmajer do Naczelnej Dyrekcji Bibliotek w Ministerstwie Oświaty, Kraków, 9 sierpnia 1949 roku.

4 AAN, sygn. 6943, k. 1-36 - Aleksander Birkenmajer, Sprawozdanie z wizytacji Biblioteki Uniwersyteckiej we Wrocławiu przeprowadzonej w dniach 14-19 czerwca 1949 r. [Kraków, 9 sierpnia 1949]. Birkenmajer uwzględnił drobne uzupełnienia, dotyczące sprawozdania, przesłane przez sekretarkę wrocławskiej zbiornicy Halinę Rupińską Biblioteka Jagiellońska w Krakowie, Korespondencja Aleksandra Birkenmajera, Przyb. 597/75 - Halina Rupińska do Aleksandra Birkenmajera, Wrocław, 7 lipca 1949 roku. 
- Bibliotekę Lekarską nastawioną na Wydział Lekarski i Weterynaryjny.

Aleksander Birkenmajer przeprowadził wizytację pierwszej z podanych wyżej, tj. Biblioteki Uniwersyteckiej, oraz wrocławskiej zbiornicy. Kontrola trwała od 14 do 21 czerwca 1949 roku. W jej wyniku sporządził obszerne sprawozdanie, liczące 36 stron, którego układ został dostosowany do Szczegółowej instrukcji wizytacyjnej dołączonej do Pisma Ministerstwa Oświaty z dnia 25 V 1949 Nr NDB/N-2071/49. Trzeba przyznać, że Naczelna Dyrekcja Bibliotek wybrała do tego celu osobę w pełni kompetentną. Birkenmajer znał doskonale od strony zarówno teoretycznej, jak i praktycznej problemy związane z powojenną ochroną zbiorów bibliotecznych oraz funkcjonowaniem bibliotek naukowych. Do połowy 1947 roku był dyrektorem Biblioteki Uniwersyteckiej w Poznaniu, a następnie dyrektorem Biblioteki Jagiellońskiej. Na mocy zarządzenia Ministra Oświaty Stanisława Skrzeszewskiego z 15 lutego 1945 roku $^{5}$ został okręgowym kierownikiem bibliotecznym, jednym z czterech w kraju. Ratował księgozbiory na obszarach Wielkopolski oraz częściowo Dolnego Śląska i Pomorza Zachodniego. W latach 1945-1947 zabezpieczył i poddał ochronie na tych terenach około 940000 tomów ${ }^{6}$. Był organizatorem i pierwszym kierownikiem poznańskiej Zbiornicy Księgozbiorów Zabezpieczonych ${ }^{7}$.

Zbiornice-segregatornie powstały 1 lutego 1947 roku, na mocy decyzji Ministerstwa Oświaty, w Gdańsku, Katowicach, Krakowie, Poznaniu, Szczecinie, Toruniu i we Wrocławiu ${ }^{8}$. Sześć z nich formalnie zostało zlikwidowanych 31 grudnia 1949 roku. Najdłużej, do 31 grudnia 1955 roku, funkcjonowała Zbiornica Księgozbiorów Zabezpieczonych

${ }^{5}$ Zarządzenie Ministra Oświaty z dnia 15 lutego 1945 roku w sprawie zabezpieczenia bibliotek, „Poznański Dziennik Wojewódzki” 1945, nr 3, poz. 17.

${ }^{6}$ R. Nowicki, Działalność Aleksandra Birkenmajera na rzecz ochrony zbiorów bibliotecznych. Ziemie zachodniej i pótnocnej Polski w latach 1945-1947, Poznań 2006, s. 248.

${ }^{7}$ Po odejściu Aleksandra Birkenmajera do Krakowa drugim kierownikiem poznańskiej zbiornicy został Bolesław Świderski - zob. A. Jazdon, Bolesław Świderski jako kierownik Zbiornicy Księgozbiorów Zabezpieczonych w Poznaniu - przyczynek do poznańskiego okresu działalności, w: Bibliotekarstwo według Bolesława Świderskiego - Myśl, praktyka, dydaktyka. Księga pamiątkowa, red. S. Kurek-Kokocińska, Łódź 2009, s. 35-55.

${ }^{8}$ Komunikat Naczelnej Dyrekcji Bibliotek Ministerstwa Oświaty o utworzeniu zbornic-segregatorni, w: A. Knot, Polskie prawo biblioteczne, Wrocław-Warszawa 1947, s. 117. W komunikacie jest mowa o utworzeniu sześciu zbiornic-segregatorni. Nie została wymieniona toruńska zbiornica, która również powstała 1 lutego 1947 roku - AAN, Ministerstwo Oświaty. Naczelna Dyrekcja Bibliotek. Wydz.[iat] Bibliotek Naukowych. Zbiornica Księgozbiorów przy Bibliotece Uniwersyteckiej w Toruniu. Sprawozdanie z działalności za lata 1947-49, sygn. 6956, k. 1 - S. Burhardt do Naczelnej Dyrekcji Bibliotek w Ministerstwie Ośziaty, Toruń, 3 kwietnia 1950 roku. 
w Katowicach ${ }^{9}$. Utworzenie zbiornic jest związane z przejściem Ministerstwa Oświaty do drugiego etapu powojennej ochrony zbiorów bibliotecznych $\mathrm{w}$ Polsce. Pierwszy polegał przede wszystkim na zabezpieczeniu księgozbiorów, drugi - na segregacji i repartycji dzieł. Jedną z siedmiu instytucji była wrocławska Zbiornica Księgozbiorów Zabezpieczonych, która obejmowała obszar Dolnego Śląska.

Należy podkreślić, iż we Wrocławiu zbiory zabezpieczone były przechowywane $\mathrm{w}$ dwóch miejscach: w Bibliotece Uniwersyteckiej i w magazynach Zbiornicy Księgozbiorów Zabezpieczonych. Poddane ochronie dzieła szczególnie interesowały Birkenmajera, który zwrócił uwagę między innymi na wyjątkowo trudną sytuację lokalową placówek.

Biblioteka Uniwersytecka w 1949 roku posiadała cztery budynki:

- I (główny) przy ul. Szajnochy 7-9,

- II przy ul. Szajnochy 10,

- III przy pl. Solnym 13,

- IV przy pl. Solnym 12.

Według opinii wizytującego żaden obiekt nie nadawał się na bibliotekę. Przed wybuchem wojny $\mathrm{w}$ dwóch $\mathrm{z}$ nich mieściły się banki, a jeden stanowił kamienicę czynszową. Nie zostały zatem wzniesione ani nie były przystosowane do celów bibliotecznych. Również budynek główny (I), w którym wcześniej funkcjonowała Biblioteka Miejska, wzbudzał wiele zastrzeżeń bibliologa. Znajdowały się $\mathrm{w}$ nim magazyny, ale o przestarzałej konstrukcji rusztowej. Niefunkcjonalne dla potrzeb biblioteki było rozplanowanie pozostałych pomieszczeń. $Z$ powodu nagromadzenia znacznej liczby dzieł panowała wewnątrz ciasnota.

W budynku II, na parterze, sortowano księgozbiory zabezpieczone w ramach "Akcji 34". Działania, zaplanowane na okres 34 miesięcy, miały na celu segregowanie księgozbiorów poniemieckich, zabezpieczonych przez Bibliotekę Uniwersytecką w latach 1945-1946 na terenie Wrocławia. W części budynku III prowadzono „Akcję 400”, która polegała na porządkowaniu i ustawianiu na regałach ocalałych książek z zasobów dawnej Staats- und Universitätsbibliothek Breslau. Liczbę zachowanych tomów oceniono na 400 000. Książek na tym etapie nie udostępniano czytelnikom oraz nie włączano ich do katalogów biblioteki. Wydzielano je do zbiorów specjalnych i przenoszono do obiektu II. Budynek IV przeznaczono na magazyn książek poniemieckich, rozsortowywanych w ramach „Akcji 34”. Wpływy książek poniemieckich do biblioteki były niewielkie. Wynosiły one za okres od 1 września 1947 roku do 31 sierpnia

91 stycznia 1956 roku stała się działem, a w 1970 roku oddziałem Biblioteki Narodowej (ostatecznie zlikwidowanym w 1999 roku). 
1948 roku zaledwie 4384 tomy (z tego tylko 304 tomy z dawnej Staatsund Universitätsbibliothek Breslau). Sytuacja ta była spowodowana tym, iż w czasie trwania wizytacji „Akcja 400” i "Akcja 34” zostały dopiero rozpoczęte. Na rezultaty należało więc jeszcze poczekać. Dodatkowa trudność wynikała z prawie całkowicie zapełnionego magazynu druków opracowanych.

W skład zbiorów Biblioteki Uniwersyteckiej wchodziły wówczas:

- zbiory dawnej Biblioteki Miejskiej, liczące około 360000 tomów;

- nabytki od 1945 roku, wykazujące na dzień 31 maja 1949 roku zasób akcesyjny wynoszący 39800 dzieł w 62424 tomach;

- ocalała część zasobów dawnej Staats- und Universitätsbibliothek Breslau, około 400000 tomów;

- poniemieckie księgozbiory, zabezpieczone przez Bibliotekę Uniwersytecką w latach 1945-194610, szacowane na ponad 600000 tomów.

"Akcję 400" rozpoczęto 28 marca 1949 roku. Odbywała się ona w budynku III, który prawie w całości został przeznaczony na dawne zasoby Staats- und Universitätsbibliothek Breslau. Księgozbiór ten niemalże całkowicie wypełniał pomieszczenia wspomnianego obiektu. Liczne sale tego budynku wyposażono w regały, na których książki miały zostać ustawione $\mathrm{w}$ porządku sygnatur, nadanych im przez dawną bibliotekę niemiecką. Były to sygnatury rzeczowe, które odpowiadały systematycznemu ustawieniu obowiązującemu w pruskich bibliotekach naukowych.

"Akcja 400" dotyczyła rekonstrukcji dawnego układu księgozbioru według treści. Prowadzenie jej zaplanowano na trzy etapy. Pierwszy polegał na segregacji według zasadniczych grup sygnaturowych, kolejny na podziale tych grup na podgrupy, a ostatni na ustawieniu pozycji według sygnatur. Etap pierwszy został wykonany w około 90\% (oprócz gazet).

Kierownikiem „Akcji 400" był Jerzy Woronczak. Ponadto uczestniczyli w niej: jeden pracownik etatowy Biblioteki Uniwersyteckiej oraz pięć osób płatnych z funduszów rzeczowych. Birkenmajer stwierdził:

Jakkolwiek "Akcja 400" jest dopiero w początkach i dużo wody upłynie w Odrze, zanim te zasoby (szacowane na 400000 tomów) zostaną całkowicie opanowane[,] tj. nie tylko rozklasyfikowane (ustawione), ale także ujęte w najbardziej bodaj rudymentarną ewidencję - to jednak już teraz można sobie zdać sprawę z tego, jak ta „Akcja” była potrzebna i jak wielkie będzie miała znaczenie, nie tylko w skali lokalnej, ale również w skali ogólnopolskiej. Jest bowiem rzeczą

10 Powojenną ochroną zbiorów bibliotecznych na Dolnym Śląsku kierował dyrektor Biblioteki Uniwersyteckiej we Wrocławiu Antoni Knot. 
jasna, że już samo ustawienie tych zasobów na półkach regałów w znacznej mierze udostępni je (dzięki sygnaturom rzeczowym) dla badaczy ${ }^{11}$.

Zbiór ten zawierał ogromną liczbę wydawnictw szczególnie cennych, zwłaszcza periodyków wydawanych przez towarzystwa naukowe, których w kraju brakowało.

Poniemieckie zasoby, zabezpieczone przez Bibliotekę Uniwersytecką w latach 1945-1946, jak wspomniano, stanowiły przedmiot "Akcji 34". Została ona rozpoczęta 4 kwietnia 1949 roku. Czynności prowadzono na parterze budynku II. Książki, które zostały przejrzane przez pracowników, a nie nadawały się do bezzwłocznego włączenia do zasadniczych zasobów Biblioteki Uniwersyteckiej, kierowano do budynku IV.

"Akcją 34" kierował Jan Ożóg. Prace prowadziły dwie oddzielne ekipy pracowników. Pierwsza, złożona z pięciu osób, miała uzupełnić zasób czasopism dawnej Biblioteki Miejskiej materiałem pozyskanym z poniemieckich zbiorów zabezpieczonych, a w przyszłości także czasopismami pochodzącymi $\mathrm{z}$ "Akcji 400”. Jakie były rezultaty rozpoczętych dwa miesiące wcześniej działań, nie udało się Birkenmajerowi ustalić, gdyż nie prowadzono statystyki.

Ekipa druga zajęta była segregacją zasobów zabezpieczonych na trzy główne kategorie:

- druki przydatne Bibliotece Uniwersyteckiej,

- druki przydatne innym polskim bibliotekom,

- makulatura.

Zespół ten składał się z 23 osób: dziewięciu sortujących, sześciu piszących kartki, dwóch układających kartki, pracownika kancelaryjnego, pięciu pracowników fizycznych. Od 4 kwietnia do 11 czerwca 1949 roku przesegregowali oni ogółem 343225 tomów, a więc około połowę zasobu. $Z$ tego na kategorię pierwszą przypadało 148049 tomów (43\%), na drugą 136738 tomów (40\%) i na trzecią, tj. makulaturę, 58468 tomów (17\%).

Do kategorii pierwszej zaliczano między innymi: rękopisy, stare druki, kartografię, muzykalia, polonika, silesiaca, lusatica, książki z zakresu bibliologii, bibliotekarstwa oraz sztuki, czasopisma, dysertacje doktorskie. Działy te, oprócz dwóch ostatnich, przesyłano niezwłocznie celem ich opracowania do zbiorów specjalnych lub akcesji (polonika). Czasopisma składano osobno, aby później je scalić. Podobnie czyniono z dysertacjami. Pozostałe druki kategorii pierwszej spisywano na miejscu prowizorycznie, m.in. w celach skompletowania wydawnictw wielotomowych czy wydzielenia dubletów. Do 11 czerwca 1949 roku spisano w ten sposób

11 AAN, sygn. 6943, k. 17 - Aleksander Birkenmajer, Sprawozdanie... 
42500 tomów kategorii pierwszej. Rejestrowanie druków kategorii drugiej odłożono na późniejszy termin.

Według obliczeń Birkenmajera przeciętna dzienna wydajność jednej osoby sortującej wynosiła 6400 tomów, a spisującej około 120 tomów. Była więc wysoka.

"Akcja 400" miała dla biblioteki większe znaczenie niż "Akcja 34". $\mathrm{Z}$ pierwszej pochodziły wyłącznie druki wartościowe. Natomiast z drugiej, do czerwca 1949 roku, wysegregowano 17\% makulatury oraz 40\% druków zbędnych dla wrocławskiej placówki, jednak przydatnych dla innych polskich bibliotek. Dane te skłoniły Birkenmajera do wysnucia przypuszczenia, że w wyniku „Akcji 34” do zbiorów Biblioteki Uniwersyteckiej zostanie wcielonych ponad 200000 tomów.

Zbiornica Księgozbiorów Zabezpieczonych dysponowała zaledwie trzema lokalami. Biuro zarządu znajdowało się na pierwszym piętrze w budynku przy ul. Cybulskiego 30-38. Jeden magazyn książek usytuowano w gmachu poklasztornym przy pl. Uniwersyteckim, a drugi w części byłej Staats- und Universitätsbibliothek Breslau przy ul. św. Jadwigi 4-6. Biuro zajmowało jeden pokój. Magazyn pierwszy składał się z czterech różnej wielkości pomieszczeń, nazwanych w sprawozdaniu ubikacjami ${ }^{12}$, natomiast drugi - z pięciu pomieszczeń, korytarza oraz sieni wjazdowej pełniącej zarazem funkcję garażu. Zbiornica dysponowała dwoma samochodami, z których w czasie wizytacji sprawny był tylko jeden.

W sprawozdaniu Birkenmajer napisał:

Praca segregacyjna i w ogóle cała manipulacja techniczna, związana z przypływem i odpływem materiału książkowego, odbywa się jedynie w magazynach, a raczej prawie wyłącznie w magazynie Nr 2, ponieważ magazyn Nr 1 jest już niemal bez reszty załadowany książkami, mocno zresztą przebranymi, do niego zatem już się nie zwozi dalszych książek a tylko od czasu do czasu odpływają z niego nieliczne ich partie, o ile wysłannik postronnej instytucji, która zabiega o przydział ministerialny, ma czas, siły i ochotę po temu, by po przeglądzie odnośnego działu w magazynie Nr 2 zainteresować się również materiałem zgromadzonym w magazynie $\mathrm{Nr} 1^{13}$.

Warunki lokalowe w magazynach były niezwykle prymitywne. Budynki zostały jedynie prowizorycznie wyremontowane, a okna magazynów nie posiadały właściwych zabezpieczeń. W większości brakowało szyb. Otwory zabito deskami lub dyktą. Wewnątrz panowały półmrok

\footnotetext{
${ }^{12}$ Ibidem, k. 32. Również tak zostały nazwane pomieszczenia drugiego magazynu.

${ }^{13}$ Ibidem.
} 
oraz wilgoć. Wadliwie działała prowizoryczna instalacja elektryczna. Magazyn pierwszy pozostawał całkowicie nieopalony, a w magazynie drugim tylko jeden lokal dogrzewano małym piecykiem żelaznym. W pomieszczeniach nie było żadnych regałów. Książki ułożono w pryzmach, sięgających najczęściej od podłogi po sufit. Zwiezione tomy, zgodnie z instrukcją Naczelnej Dyrekcji Bibliotek, dzielono na 28 działów. O bogatej różnorodności zabezpieczonych książek świadczył fakt, że wszystkie działy były reprezentowane $\mathrm{w}$ magazynach.

Warunki lokalowe w biurze zbiornicy, w którym prowadzono czynności wyłącznie administracyjne, zostały ocenione przez Birkenmajera jako dobre. Panował tutaj wzorowy porządek. Personel zbiornicy składał się z kierownika dra Edwarda Zubika ${ }^{14}$, sekretarki Haliny Rupińskiej, referenta terenowego, trzech osób segregujących, dwóch szoferów-mechaników i pięciu pracowników fizycznych, z których jeden lub dwóch stale zaangażowanych było $\mathrm{w}$ zbiornicy, a pozostali w terenie.

Praca w zbiornicy polegała na:

- zbieraniu informacji o księgozbiorach i penetracji terenu, zabezpieczaniu książek w miejscach ich odnalezienia,

- wyjazdach samochodem ciężarowym w teren i zwózce książek,

- segregacji zwiezionego materiału,

- wydawaniu książek na podstawie przydziałów ministerialnych.

W czerwcu 1949 roku na terenie działalności Zbiornicy, jak wynika z informacji podanych przez Birkenmajera, prawie już nie natrafiano na zwarte księgozbiory, jednolite pod względem proweniencji. Jednak

${ }^{14}$ Edward Zubik (12 września 1907 - 4 maja 2000), pracownik naukowy Uniwersytetu Wrocławskiego, współorganizator i dziekan Wydziału Nauk Przyrodniczych, kierownik Katedry i Zakładu Fizjologii Zwierząt Instytutu Zoologicznego. Urodzony w Bóbrce (woj. lwowskie). Absolwent Uniwersytetu Jana Kazimierza we Lwowie. Uczestnik podziemnego ruchu oporu w czasie II wojny światowej. Po upadku powstania warszawskiego wywieziony przez Niemców 1 października 1944 roku do obozu pracy przymusowej we Wrocławiu, w którym przebywał do 7 maja 1945 roku. Od 12 maja tego roku pracował we wrocławskiej Delegaturze Ministerstwa Oświaty (do 31 grudnia 1945 roku był kierownikiem Referatu Transportu Delegatury). Aktywnie uczestniczył w zabezpieczaniu i organizacji uniwersytetu i politechniki oraz rewindykacji mienia naukowego wywiezionego z Wrocławia i terenów Polski centralnej. Od lutego 1947 do lipca 1951 roku kierował Zbiornicą Księgozbiorów Zabezpieczonych. Ratował zbiory biblioteczne na terenie województw wrocławskiego, częściowo opolskiego i ziemi lubuskiej - Archiwum Uniwersytetu Wrocławskiego, Zubik Edward s. Piotra l. 1945-1977, sygn. RK-120. Zob. E. Zubik, Pionierski czas nauki, w: Wspomnienia wrocławskich pionierów, wyd. W. Suleja, Wrocław 1995, s. 124-128; idem, Jak rozpoczałtem motoryzacje we Wroctawiu, w: Wspomnienia wrocławskich pionierów, wyd. W. Suleja, Wrocław 1995, s. 72-74. 
w kilku punktach województwa dolnośląskiego stwierdzono ich istnienie. Liczyły one po kilka tysięcy tomów. Wyjątkowa sytuacja zaistniała w Woliborzu. Zbiornica zabezpieczyła prawie wagon beletrystyki i literatury popularnonaukowej. Transport do Wrocławia całych nakładów był jednak niemożliwy z powodu braku miejsca w magazynach. Birkenmajer stwierdził:

Poza tem chodzi już tylko o mniej lub więcej przypadkową i mniej lub więcej ilościowo obfitą „zbieraninę" książek. Np. Samopomoc Chłopska zbiera je po chłopach, sama odrzuca "makulaturę", resztę przekazuje do dyspozycji Zbiornicy. Na ogół, obecni posiadacze książek (poniemieckich) odnoszą się nieżyczliwie do tej akcji, uważając, że książki te są ich legalną własnością wzgl.[ędnie], że należy im się odszkodowanie za trudy i wydatki, poniesione przy ich „zabezpieczeniu". Wypada dodać, że ta akcja Samopomocy Chłopskiej nie była brana pod uwagę w planowaniach Zbiornicy; jest to akcja dodatkowa, zmierzająca do likwidacji małych ilościowo książek poniemieckich, które się znalazły w prywatnym ręku. Zbiornica jako taka nie ma możliwości zabierania takich drobnych ilości książek, a (jak się okazało) ostatni transport, w ilości ok. 4000 tomów, przekazany przez Samopomoc Chłopska, przedstawia znaczną wartość ${ }^{15}$.

Pomimo że działalność zbiornic w kraju dobiegała końca - Ministerstwo Oświaty formalnie zakończyło pracę tych placówek z końcem grudnia 1949 roku (z wyjątkiem Zbiornicy w Katowicach) - Zbiornica Księgozbiorów Zabezpieczonych we Wrocławiu nadal zwoziła dziesiątki tysięcy tomów. O obfitości książek może świadczyć fakt, że w czerwcu tego roku nikt nie był w stanie udzielić odpowiedzi Birkenmajerowi, ile księgozbiorów pozostało jeszcze w terenie. W skali całej Polski na obszarze Dolnego Śląska występowało ich największe nagromadzenie. Były to zbiory głównie poniemieckiej proweniencji, $\mathrm{w}$ tym przewiezione podczas wojny z Berlina, celem ich ochrony przed spodziewanymi nalotami na stolicę III Rzeszy. Najcenniejsze z nich zostały zabezpieczone w latach 1945-1946, ale - jak wynika z powyższych informacji - w dalszym ciągu znajdowano wartościowe materiały biblioteczne.

Niezwykle cenne informacje zawarte w sprawozdaniu dotyczą ilości zabezpieczonych zbiorów. Otóż wyjazdy samochodem ciężarowym w teren powodowały, że miesięcznie do magazynu drugiego zwożono około 30000 tomów. Liczba książek przesegregowanych równała się liczbie książek zwiezionych. O przydziałach dla poszczególnych instytucji w kraju decydowało Ministerstwo Oświaty. Zbiornica prawie co miesiąc wysyłała

15 AAN, sygn. 6943, k. 34 - Aleksander Birkenmajer, Sprawozdanie... 
sprawozdanie do Naczelnej Dyrekcji Bibliotek - od maja 1947 do czerwca 1949 roku skierowała 22 takie pisma. Do wszystkich dokumentów miał wgląd we Wrocławiu Birkenmajer. Wynikało z nich, że segregowano od 25000 do 45000 tomów, tj. ponad 30000 tomów miesięcznie. Ogólna liczba już przesegregowanych materiałów wynosiła około 700000 tomów. Odpływ książek był zdecydowanie mniejszy. W 1947 roku wynosił zaledwie 11332 tomy, w 1948 roku wzrósł do 133299 tomów, a do czerwca 1949 roku wydano 70249 tomów. Zatem ogółem przekazano 214880 tomów, w tym około 50000 przejęła Biblioteka Sejmowa. W zbiornicy pozostawało jeszcze około 500000 tomów. W większości były to „książki drugorzędnej i trzeciorzędnej wartości, jakkolwiek niewątpliwie są jeszcze wśród nich cenne a nawet bardzo cenne" ${ }^{\prime 16}$. Zorientowanie się co do ich wartości sprawiało dużą trudność. Dostępu do książek nie ułatwiało ułożenie tomów w wysokie pryzmy. $Z$ tego też powodu delegaci różnych instytucji zgłaszający się po ministerialny przydział dzieł po kilkugodzinnych lub kilkudniowych poszukiwaniach przydatnej literatury przerywali żmudną pracę i zadowalali się połowicznymi wynikami. Sytuacja ta hamowała odpływ książek ze zbiornicy. Najlepszym wyjściem byłoby zgromadzenie $\mathrm{w}$ jednym lokalu, wyposażonym $\mathrm{w}$ repozytoria, całego półmilionowego zasobu. Birkenmajer zdawał sobie doskonale sprawę $\mathrm{z}$ tego, że jest to rozwiązanie czysto teoretyczne. We Wrocławiu nie było wówczas takich możliwości. Postulował natomiast rozważenie hurtowego pozbycia się poniemieckich nakładów księgarskich z zakresu beletrystyki i literatury popularnonaukowej. W magazynie drugim widział stosy nakładów Dietricha, a do zbiornicy zgłaszali się chętni nabywcy. Pracownicy nie mogli jednak sprzedać książek bez stosownego upoważnienia Ministerstwa Oświaty. Poprawę ciężkich warunków lokalowych zbiornicy słusznie Birkenamjer widział w częściowym spieniężeniu nakładów oraz oddaniu książek o wartości makulatury na przemiał.

Wrocławska zbiornica posiadała filię w Chojnowie w powiecie legnickim. Zatrudnionych w niej było dwóch pracowników: umysłowy i fizyczny. Ze względu na ograniczony czas trwania wizytacji profesor nie zdołał jednak odwiedzić placówki. Znajdowało się w niej około 70000 tomów posegregowanych na działy. $Z$ tej filii z powodu rzadkich przyjazdów osób zainteresowanych wydano zaledwie około 900 tomów.

Aleksander Birkenmajer w sprawozdaniu informował Ministerstwo Oświaty o występowaniu nadal na terenie Dolnego Śląska księgozbiorów. Zbiornica pomimo formalnego zakończenia działalności 31 grudnia 1949 roku w dalszym ciągu zwoziła książki. Wiadomości o tym dostarczają

${ }^{16}$ Ibidem, k. 35. 
późniejsze materiały źródłowe ${ }^{17}$, które w pełni potwierdzają sygnały skierowane przez wizytującego do ministerstwa.

Do wrocławskiej zbiornicy ogółem w latach 1947-1949 zwieziono 877958 tomów ${ }^{18}$. Wszystkie księgozbiory zostały przesegregowane. $\mathrm{Z}$ tego jedynie 190342 tomy wydano innym instytucjom na terenie kraju (m.in.: Akademii Górniczo-Hutniczej w Krakowie, Bibliotece Uniwersyteckiej we Wrocławiu, Głównemu Urzędowi Statystycznemu w Warszawie, Ministerstwu Kultury i Sztuki w Warszawie, Muzeum Wojska Polskiego w Warszawie, Uniwersytetowi Jagiellońskiemu w Krakowie, Uniwersytetowi Łódzkiemu, Uniwersytetowi Mikołaja Kopernika w Toruniu, Uniwersytetowi Poznańskiemu, Uniwersytetowi Warszawskiemu). Stan wrocławskiej zbiornicy 31 grudnia 1949 roku wynosił 687616 tomów ${ }^{19}$. W wyniku dalszego transportowania książek $\mathrm{z}$ terenu liczba ogólna wzrosła pod koniec lutego 1950 roku do 707187 tomów ${ }^{20}$, a we wrześniu tego roku do 767987 tomów ${ }^{21}$. Stan zbiornicy 31 grudnia 1950 roku wynosił 760629 tomów ${ }^{22}$. Z likwidowanej w latach 1951-1952 wrocławskiej zbiornicy ${ }^{23}$ skierowano do Bytomia ${ }^{24} 500000$ książek $^{25}$. Z Biblioteki Uniwersyteckiej we Wrocławiu przekazano 210000 woluminów,

17 Sporządzone po wizytacji przeprowadzonej przez Aleksandra Birkenmajera.

18 AAN, Ministerstwo Oświaty. Naczelna Dyrekcja Bibliotek. Wydz.[iał] Bibliotek Naukowych. Zbiornica Księgozbiorów Zabezpieczonych we Wrocławiu. Sprawozdania miesięczne z działalności za 1950 r., sygn. 6959, k. 2 - Stan Zbiornicy na dzień 30 XII 1949 r.

${ }^{19}$ Ibidem. W sprawozdaniu zatytułowanym Stan Zbiornicy na dzień 30 XII 1949 r. podano stan na 31 grudnia.

${ }^{20}$ AAN, Ministerstwo Oświaty. Naczelna Dyrekcja Bibliotek. Wydz.[iat] Bibliotek Naukowych. Zbiornica Księgozbiorów Zabezpieczonych we Wrocławiu. Sprawozdania miesięczne z działalności za 1950 r., sygn. 6959, k. 4 - E. Zubik, Sprawozdanie rzeczowe za miesiąc luty $1950 \mathrm{r}$.

21 AAN, Ministerstwo Oświaty. Naczelna Dyrekcja Bibliotek. Wydz.[iał] Bibliotek Naukowych. Zbiornica Księgozbiorów Zabezpieczonych we Wrocławiu. Sprawozdania miesięczne z działalności za 1950 r., sygn. 6959, k. 26 - E. Zubik, Sprawozdanie rzeczowe za miesiąc maj $1950 \mathrm{r}$.

22 AAN, Ministerstwo Oświaty. Naczelna Dyrekcja Bibliotek. Wydz.[iat] Bibliotek Naukowych. Zbiornica Księgozbiorów Zabezpieczonych we Wrocławiu. Sprawozdania miesięczne z działalności za 1950 r., sygn. 6959, k. 30 - E. Zubik, Roczne sprawozdanie rzeczowe za rok 1950.

${ }^{23}$ Zbiornica Księgozbiorów Zabezpieczonych w Katowicach zajmowała się likwidacją innych zbiornic, w tym we Wrocławiu.

${ }^{24} \mathrm{~W}$ Bytomiu znajdował się magazyn katowickiej Zbiornicy Księgozbiorów Zabezpieczonych.

${ }^{25}$ F. Szymiczek, Akcja zabezpieczania bibliotek i księgozbiorów na Śląsku w świetle dokumentów i wspomnień własnych, „Książnica Śląska” 1975-1978, t. 20, s. 50-51. 
a kolejnych 90000 woluminów przygotowano do wysyłki. Z tego, po wstępnej selekcji, oddano na makulaturę 300000 woluminów, a z Biblioteki Uniwersyteckiej 140000 woluminów.

Aleksander Birkenmajer okazał się wnikliwym i dociekliwym wizytatorem wrocławskiej Zbiornicy Księgozbiorów Zabezpieczonych. Nie ograniczał się jedynie do opisu oraz stwierdzania faktów, ale zgłaszał propozycje rozwiązania istniejących problemów. Dostrzegał trudną sytuację lokalową zbiornicy oraz Biblioteki Uniwersyteckiej, w której również znajdowało się kilkaset tysięcy zabezpieczonych książek. Przedstawione w sprawozdaniu wnioski i propozycje były słuszne. Trzeba również pamiętać o czasie, w którym odbyła się wizytacja - zaledwie cztery lata po zakończeniu wojny. W zniszczonym Wrocławiu, zamienionym przez hitlerowców na twierdzę, brakowało budynków mogących zaspokoić ogromne potrzeby biblioteczne, a także specjalistów bibliotekarzy. Nadal borykano się z licznymi podstawowymi przeszkodami, w tym przykładowo z właściwym zabezpieczeniem pomieszczeń magazynowych. Brakowało między innymi podstawowych pomocy ułatwiających segregowanie i katalogowanie, a zwłaszcza bibliografię. Warunki lokalowe dostosowywano do istniejących wówczas skromnych możliwości. Na podkreślenie zasługuje fakt, iż pomimo ogromnych zniszczeń i występujących trudności udało się pracownikom ocalić wartościowy materiał biblioteczny, głównie poniemieckiej proweniencji. Zasoby zgromadzone w zbiornicy pozwoliły odbudować oraz uzupełnić zbiory biblioteczne we Wrocławiu i w wielu instytucjach naukowych na terenie kraju. Skatalogowane tomy zaczęły służyć studentom oraz ludziom nauki. Wiarygodne źródło informuje o przetrwaniu licznych poniemieckich księgozbiorów na terenie Dolnego Śląska. Kilkaset tysięcy tomów ze zlikwidowanej zbiornicy, uznanych za zbędne i mające wartość makulatury, zostało na początku lat 50. przetransportowanych do Zbiornicy Księgozbiorów Zabezpieczonych w Katowicach, a następnie oddanych na przemiał. Wśród nich mogły być również cenne pozycje, o czym sygnalizował w 1949 roku bibliolog.

Aleksander Birkenmajer z nałożonego przez Naczelną Dyrekcję Bibliotek obowiązku wywiązał się sumiennie. Ze względu na ściśle określony czas trwania wizytacji nie zdołał wyczerpująco zgłębić wszystkich spraw. Miał tego pełną świadomość. Sporządzone przez bibliologa sprawozdanie cechują fachowość, solidność i obiektywizm. A trzeba pamiętać, iż była to pierwsza wizytacja Birkenmajera ${ }^{26}$.

${ }^{26}$ Następne wizytacje Aleksander Birkenmajer planował przeprowadzić w Bibliotece Narodowej oraz w Bibliotece Uniwersyteckiej w Warszawie. 
Zachowany dokument jest cennym materiałem źródłowym pozwalającym poznać nie tylko Aleksandra Birkenmajera jako rzetelnego wizytatora, ale także fragment historii zbiornicy i Biblioteki Uniwersyteckiej. Zawiera on wiele interesujących szczegółów, nieznanych dotychczas w literaturze przedmiotu. Sprawozdanie ma dużą wartość poznawczą. Powinno być wykorzystane w przyszłych pracach badawczych związanych z odbudową bibliotek i bibliotekarstwa na Dolnym Śląsku oraz w Polsce.

\author{
RYSZARD NOWICKI
}

\title{
Aleksander Birkenmajer as the inspector of the Secured Book Collection Repository in Wrocław
}

\begin{abstract}
Aвstract. One of the most prominent Polish bibliologists of the twentieth century, Prof. Aleksander Birkenmajer, conducted in 1949 his first ever library inspection, commissioned by the Ministry of Education, at the University Library and the Secured Book Collection Repository in Wrocław. Both institutions held at the time library materials that were under special surveillance. Between 1947 and 1949, the Repository received about 900,000 volumes of mainly German provenience from Lower Silesia. In his subsequent report, Birkenmajer indicated the existing problems and proposed some ways to overcome them. He also highly praised the staff in charge of the collections who demonstrated their commitment and expertise in such harsh working conditions in this hard post-war period.

Aleksander Birkenmajer proved to have been an insightful, solid, highly efficient and objective inspector. His Report is a valuable document and source material for a better understanding of the history of the Wrocław-based Repository and the University Library in Wrocław. Undoubtedly, the report should be included in any future research work concerning the reconstruction and rebuilding of libraries and librarianship in Lower Silesia and in Poland.
\end{abstract}

KEY wORDs: Aleksander Birkenmajer, preservation of library resources, Wrocław, Lower Silesia, book repository, the 20th century. 
